\title{
Physicochemical Quality Changes in Tomatoes during Delayed Cooling and Storage in a Controlled Chamber
}

\author{
Md. Shaha Nur Kabir ${ }^{1} \oplus$, Mohammod Ali ${ }^{2,3}$, Wang-Hee Lee ${ }^{2,3}$, Seong-In Cho ${ }^{4}$ \\ and Sun-Ok Chung $2,3, *$ D \\ 1 Department of Agricultural and Industrial Engineering, Faculty of Engineering, Hajee Mohammad Danesh \\ Science and Technology University, Dinajpur 5200, Bangladesh; msnkhstu@gmail.com \\ 2 Department of Agricultural Machinery Engineering, College of Agriculture and Life Sciences, \\ Chungnam National University, Daejeon 34134, Korea; shohag.aet@gmail.com (M.A.); \\ wanghee@cnu.ac.kr (W.-H.L.) \\ 3 Department of Smart Agricultural Systems, Chungnam National University, Daejeon 34134, Korea \\ 4 Department of Biosystems and Biomaterials Science and Engineering, College of Agriculture \\ and Life Sciences, Seoul National University, Seoul 08826, Korea; sicho@snu.ac.kr \\ * Correspondence: sochung@cnu.ac.kr; Tel.: +82-42-821-6712; Fax: +82-42-823-6246
}

Received: 11 May 2020; Accepted: 30 May 2020; Published: 1 June 2020

\begin{abstract}
The exposure of tomato fruits to unfavorable environments during the postharvest could result in severe losses along the supply chain. In this research, four tomato cultivars were stored in a controlled chamber under three levels of postharvest conditions to investigate the effects of delayed cooling on selected physicochemical quality parameters of the tomatoes. The tomato cultivars were subjected to three postharvest treatments: Immediate storage (IS) at harvest day; delayed storage (DS), leaving tomatoes without cover for one day; and under cover (DSC), separately in a greenhouse, and then stored in a controlled chamber at a temperature of $10 \pm 1{ }^{\circ} \mathrm{C}$ and relative humidity of $90 \% \pm 3 \%$. Fresh weight, firmness, total soluble solids (TSS), and hue angle $\left(h^{\circ}\right)$ were examined over 15 days, every 5 days. Among the tomato cultivars, Cherry (7160), treated under DS showed the highest weight loss (13.01\%) and firmness loss (42.14\%) after 15 days of storage. Dabol (large) tomatoes treated with DS showed higher changes in TSS $\left({ }^{\circ} \mathrm{Bx}\right)$ values (4.79 to 5.76). Low changes in hue angle values were found in IS-treated Cherry (7160) tomatoes at the end of the storage period. Overall quality changes were slower for all tomato cultivars treated with IS than with other treatments throughout the storage period. This study indicated the importance of reducing cooling delays to maintain the quality during the postharvest and prolong storage of harvested tomatoes.
\end{abstract}

Keywords: postharvest handling; cooling delay; quality parameter; storage; tomato

\section{Introduction}

Demand for tomatoes (Solanum lycopersicum L.) has been increasing recently due to the nutritional value related to the carotenoids, fibers, and vitamins they contain [1-3]. Consuming carotenoids from tomatoes is associated with reduced risk of cancer and incidence of heart diseases [4,5]. The postharvest storage of tomato is affected by numerous interrelated factors such as tomato variety, climatic conditions, cultivation conditions, degree of ripeness during harvest, and storage conditions [6-8]. The postharvest handling, from harvest to storage place, significantly affects the quality of tomatoes during harvest, and in the subsequent marketing procedures, including long-term storage or transportation [9]. It is important that the quality of tomatoes is well-maintained during storage or transportation; even the quality of processed products is affected by postharvest handling procedures. 
Tomatoes are sensitive products that are highly vulnerable to abnormal treatment, impact loads, and vibrations during transportation, storage, and marketing processes [10]. In particular, the postharvest storage condition in an environment-controlled facility is crucial to retain the characteristics of tomatoes. Therefore, maintaining optimum environmental conditions is critical to reduce postharvest losses of tomatoes [11].

Temperature and relative humidity are vital environmental factors affecting the quality and storage life of horticultural commodities. Changes in temperature and humidity can cause severe injuries to harvested horticultural commodities [12]. Tomatoes do not tolerate low temperatures below $10^{\circ} \mathrm{C}$, while high temperatures can accelerate their respiration rate $[13,14]$. Temperature control throughout the period between harvest and consumption has been found to be the most important factor in maintaining the quality of fruits and vegetables $[15,16]$. Tomatoes stored at low relative humidity (below $85 \%$ to $90 \%$ ) levels can shrivel, whereas completely saturated atmospheres of $100 \%$ relative humidity may encourage mold and fungal development [17].

Quality degradation during storage is one of the greatest issues for postharvest fruits and vegetables $[18,19]$. The most important goals of postharvest handling are to keep the product cool to avoid moisture loss and slow down undesirable chemical changes, and to avoid physical damage [20]. Delays in the cooling of horticultural products can result in both direct losses (water loss and decay) and indirect losses (decrease in flavor and nutritional quality) [21]. The shelf-life of products can be improved by reducing the cooling delay [22]. After harvest, shade can prevent an excessive temperature rise for fresh products and can reduce the ambient temperature, while the temperature of products directly exposed to sunlight could be higher (about $4-6^{\circ} \mathrm{C}$ ) than the ambient temperature [23].

Postharvest quality parameters such as weight loss, total soluble solids (TSS) content, firmness, and color changes of tomatoes determine their acceptance by wholesale buyers and consumers [24-26], and can be well-managed through proper postharvest handling techniques. Many studies have dealt with extending the storage period and shelf-life of tomatoes via various treatments and storage conditions [27-30], but few reports have been made on the consequences of a short-term cooling delay on the quality of stored tomatoes. Therefore, the aim of this study was to investigate the effects that three different postharvest storage conditions (immediate storage and delayed cooling treatments with and without cover for $24 \mathrm{~h}$ ) have on selected physicochemical quality parameters of tomato varieties stored in a controlled chamber.

\section{Materials and Methods}

\subsection{Tomato Samples and Delayed Cooling Treatments}

Four hybrid tomato cultivars (intermediate Dabol-large, intermediate Dabol-medium, Cherry-Sense Q, and Cherry-7160) were cultivated in the middle region of the Republic of Korea and harvested in May 2016. Tomatoes with relatively similar size and free from defects were harvested at red maturity stage and immediately transported from the field to the storage places. Three postharvest storage treatments were applied in two storage conditions (greenhouse and controlled chamber). The treatments were immediate storage (IS) in a controlled chamber (without any cooling delay), storage in the controlled chamber after delayed storage (DS), and delayed storage under cover (DSC) in a greenhouse (delayed cooling treatments for $24 \mathrm{~h}$ ). The tomato samples of each cultivar were put in a greenhouse for 1 day to simulate the farmers cooling delay practice, then stored in the controlled chamber for 14 days. For each cultivar, one group of tomato samples was stored on the harvest day (day 0 ) inside the controlled chamber, and the other two groups of tomato samples were put separately inside the greenhouse with and without cover on the same day.

\subsection{Storage Conditions}

The delayed cooling treatments were performed in a greenhouse $(7.5 \times 5.5 \times 3.5 \mathrm{~m})$ for $24 \mathrm{~h}$, and the IS treatments were performed in a controlled chamber $(6.5 \times 4.5 \times 3 \mathrm{~m})$. During the delayed cooling of 
tomatoes in the greenhouse, four sensor nodes including temperature and humidity sensors (AM2315, Aosong Electronics Co., Ltd., Guangzhou, China) were placed inside the greenhouse, outside of the greenhouse, and in the tomato storage boxes (uncovered and covered), respectively, to monitor the environmental conditions.

During the $24 \mathrm{~h}$ delayed cooling of tomatoes, the temperature and humidity levels of the DS-treated tomato samples inside the greenhouse were $27-40{ }^{\circ} \mathrm{C}$ and $45 \%-82 \%$, respectively, while $22-38{ }^{\circ} \mathrm{C}$ and $50 \%-85 \%$ were recorded for the DSC-treated samples. The outside temperature and humidity of the greenhouse were recorded as $18-28^{\circ} \mathrm{C}$ and $31-72 \%$, respectively. Inside the controlled chamber, the temperature and humidity were maintained at $10 \pm 1{ }^{\circ} \mathrm{C}$ and $90 \% \pm 3 \%$, respectively (Figure 1).
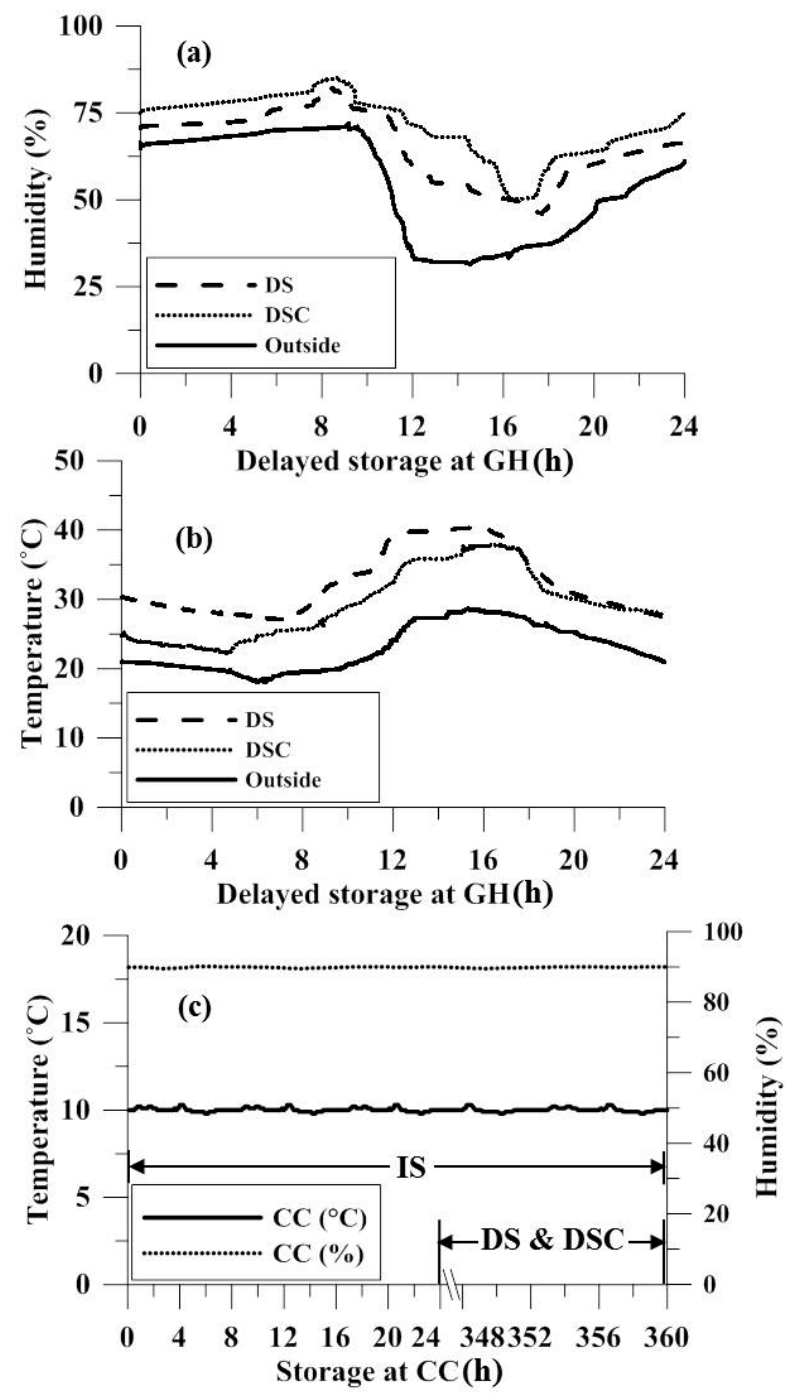

Figure 1. Temperature and humidity status for the delayed storage (DS) and delayed storage under cover (DSC)-treated tomatoes $(\mathbf{a}, \mathbf{b})$ during $24 \mathrm{~h}$ delayed cooling in the greenhouse $(\mathrm{GH})$ and inside the controlled chamber (CC) for immediate storage (IS), DS, and DSC-treated tomatoes (c).

\subsection{Experimental Design and Statistical Analysis}

Tomato samples from each cultivar were allocated to the IS, DS, and DSC treatments. A group of 10 sample fruits was taken for each storage treatment with three replications. For each cultivar, there were 30 samples for each treatment evaluated 4 times, and a total of 360 tomatoes were taken for evaluation under these treatments ( 10 samples $\times 3$ replications $\times 3$ treatments $\times 4$ times). 
The quality characteristics of the sample tomato fruit were measured on the harvest day (Day 0) and the tomatoes were immediately put into the three storage conditions. After $24 \mathrm{~h}$, the DSand DSC-treated samples were also moved into the controlled chamber and stored continuously. The evaluations of the quality characteristics of the stored tomatoes were done at 5 day intervals $(5,10$, and 15 days after storage). The details of the experimental design of this study are presented in Table 1 .

Table 1. Experimental design for the study under IS (immediate storage), DS (storage delayed $24 \mathrm{~h}$ ), and DSC (storage delayed $24 \mathrm{~h}$ under cover) postharvest treatments.

\begin{tabular}{ccc}
\hline Item & Description \\
\hline Tomato cultivar & Dabol (large), Dabol (medium), Cherry & \\
Treatment & (Sense Q), and Cherry (7160) & 3 replications \\
Storage period & IS, DS, and DSC & \\
& IS: 15 days in controlled chamber \\
& DS and DSC: 1 day (delayed cooling) in & 3 \\
Main factors and their interactions & GH and 14 days in CC & 4 \\
& Treatments & 4 \\
Environmental factors & Storage period (intervals) & \\
& Creenhouse (variable): $18-39{ }^{\circ} \mathrm{C}, 40-85 \%$ & \\
& Controlled chamber (constant): $10 \pm 1{ }^{\circ} \mathrm{C}$ & and $90 \% \pm 3 \%$ \\
\hline
\end{tabular}

The experimental data were subjected to an analysis of variance (ANOVA) using the SAS software package (version 9; SAS Corporation, Cary, NC, USA). In the statistical analysis, a three-way ANOVA was applied with three main factors, namely, postharvest storage treatment, cultivar, and storage period. Comparisons among the means were determined via Duncan's multiple range tests at a 5\% significance level.

\subsection{Quality Parameters}

\subsubsection{Weight Loss}

Tomato fruits were weighed before being placed in each storage condition, which gave the initial weight (at harvest) of the fruits. The weight loss of the tomato samples was determined by considering the differences between the initial weight and final weight (at each storage interval) of the tested tomato divided by the initial weight [31]. The weight loss was expressed as a cumulated percentage of weight loss from the initial weight of the tomato.

$$
\text { Weight loss }(\%)=\frac{\text { Initial weight }- \text { Final weight }}{\text { Initial weight }} \times 100
$$

\subsubsection{Firmness}

The tomato fruit firmness was determined using a penetrometer (model: TMS-Pro, Food Technology Corporation, Sterling, VA, USA) by measuring the force required to make a predetermined piercing using a standard probe. The tomatoes were compressed by the probe to a $5 \mathrm{~mm}$ penetration depth using a conical plate at a speed of $50 \mathrm{~mm} / \mathrm{min}$ [32].

\subsubsection{Total Soluble Solids (TSS)}

Tomato fruits were wrapped with four layers of cheesecloth and juice was extracted using a juice extractor (model: FruX80, Goojung Engineering Co. Ltd., Seoul, Korea). The Brix value was measured using a handheld digital refractometer (model: PR-32a, Atago Co. Ltd., Tokyo, Japan). 


\subsubsection{Hue Angle $\left(h^{\circ}\right)$}

The color parameters $\left(L^{*}, a^{*}\right.$, and $\left.b^{*}\right)$ of tomatoes were measured according to the approach of Helyes et al. [6] using a colorimeter (model: CR-400; Konica Minolta Inc., Tokyo, Japan) equipped with an illuminant D65 and using an $8 \mathrm{~mm}$ aperture of the instrument for illumination and measurement. Prior to color measurement, the calorimeter was calibrated using a white standard tile supplied by the company. The measured $a^{*}$ and $b^{*}$ values of the tomato fruits were used to estimate hue angle $\left(h^{\circ}\right)$ values, calculated as $\tan ^{-1}\left(b^{*} / a^{*}\right)$, which represented the position of the determined color wheel (red-purple at $0^{\circ}$, yellow at $90^{\circ}$, blue-green at $180^{\circ}$, and blue at $270^{\circ}$ ). The $h^{\circ}$ value was used to evaluate the color of the tomato skin for each storage condition throughout the storage period, following the procedures of Topuz et al. [33].

\section{Results and Discussion}

\subsection{Properties of the Tomato Cultivars at Harvest}

The properties of the four tomato cultivars at harvest are shown in Table 2. Significant differences were found between the tomato cultivars for the diameter and weight, with Dabol (large) being the highest and Cherry (7160) being the smallest. Significant differences were also found for diameters between the treatments of all cultivars, but no significant differences were found for the weight of Dabol (large) and Cherry (7160) cultivars. Significant differences were also observed between the treatments for the firmness of Dabol (large), Dabol (medium), and Cherry (7160) cultivars; where significant differences were observed for the TSS content of Dabol (large) and Dabol (medium) cultivars. No significant differences between the treatments were found for the hue angle values of Dabol (large) and Dabol (medium) cultivars. Firmness, TSS content, and hue angle values were higher for Cherry (Sense Q), Cherry (7160), and Dabol (large) cultivars, whereas these values were lower for Dabol (large).

Table 2. Properties of the tomato cultivars at harvest.

\begin{tabular}{|c|c|c|c|c|c|}
\hline \multirow{2}{*}{ Property } & \multirow{2}{*}{ Treatment } & \multicolumn{4}{|c|}{ Tomato Variety } \\
\hline & & $\begin{array}{c}\text { Dabol } \\
\text { (Large) }\end{array}$ & $\begin{array}{c}\text { Dabol } \\
\text { (Medium) }\end{array}$ & $\begin{array}{c}\text { Cherry } \\
\text { (Sense Q) }\end{array}$ & $\begin{array}{l}\text { Cherry } \\
(7160)\end{array}$ \\
\hline \multirow{3}{*}{ Diameter $(\mathrm{cm})$} & IS & $7.07 \pm 0.05^{\mathrm{Ba}}$ & $4.82 \pm 0.05^{\mathrm{Cb}}$ & $2.61 \pm 0.03^{\mathrm{Ac}}$ & $2.14 \pm 0.03^{\mathrm{Bd}}$ \\
\hline & DS & $7.59 \pm 0.07 \mathrm{Aa}$ & $5.85 \pm 0.01 \mathrm{Ab}$ & $2.45 \pm 0.01 \mathrm{Cc}$ & $2.25 \pm 0.01 \mathrm{Ad}$ \\
\hline & DSC & $6.82 \pm 0.03 \mathrm{Ca}$ & $5.68 \pm 0.08^{\mathrm{Bb}}$ & $2.55 \pm 0.03 \mathrm{Bc}$ & $2.08 \pm 0.06^{\mathrm{Bd}}$ \\
\hline \multirow{3}{*}{ Weight (g) } & IS & $170.04 \pm 3.53 \mathrm{Aa}$ & $140.10 \pm 3.85^{\mathrm{Bb}}$ & $13.73 \pm 0.47 \mathrm{Ac}$ & $10.13 \pm 0.32 \mathrm{Ac}$ \\
\hline & DS & $175.81 \pm 5.79 \mathrm{Aa}$ & $153.13 \pm 2.83 \mathrm{Ab}$ & $11.94 \pm 0.71^{\mathrm{Bc}}$ & $10.51 \pm 0.42^{\mathrm{Ac}}$ \\
\hline & DSC & $167.71 \pm 8.95$ Аа & $151.08 \pm 6.05^{\mathrm{Ab}}$ & $12.28 \pm 0.27^{\mathrm{Bc}}$ & $10.08 \pm 0.30^{\mathrm{Ac}}$ \\
\hline \multirow{3}{*}{ Firmness (N) } & IS & $28.84 \pm 2.95 \mathrm{Aa}$ & $25.28 \pm 1.38 \mathrm{Aa}$ & $31.99 \pm 4.02 \mathrm{Aa}$ & $26.95 \pm 1.66^{\mathrm{Aa}}$ \\
\hline & DS & $15.78 \pm 1.48^{\mathrm{Bd}}$ & $23.91 \pm 0.79 \mathrm{Ac}$ & $34.24 \pm 2.96 \mathrm{Aa}$ & $29.02 \pm 3.02 \mathrm{Ab}$ \\
\hline & DSC & $20.85 \pm 4.54 \mathrm{ABb}$ & $24.69 \pm 0.49 \mathrm{Aab}$ & $29.33 \pm 4.75 \mathrm{Aa}$ & $27.29 \pm 2.39 \mathrm{Aab}$ \\
\hline \multirow{3}{*}{$\begin{array}{l}\text { Total soluble } \\
\text { solids ( }{ }^{\circ} \text { Brix) }\end{array}$} & IS & $3.98 \pm 0.05^{\mathrm{Bc}}$ & $4.59 \pm 0.23^{\mathrm{Ab}}$ & $8.53 \pm 0.31 \mathrm{Aa}$ & $8.69 \pm 0.43^{\mathrm{Aa}}$ \\
\hline & DS & $4.79 \pm 0.55^{\mathrm{Ab}}$ & $4.26 \pm 0.15^{\mathrm{Bb}}$ & $7.97 \pm 0.42 \mathrm{Aa}$ & $8.57 \pm 0.61 \mathrm{Aa}$ \\
\hline & DSC & $4.19 \pm 0.11 \mathrm{ABb}$ & $3.98 \pm 0.05^{\mathrm{Bb}}$ & $8.41 \pm 0.59 \mathrm{Aa}$ & $8.81 \pm 0.28^{\mathrm{Aa}}$ \\
\hline \multirow{3}{*}{ Hue angle $\left(h^{\circ}\right)$} & IS & $68.6 \pm 3.51 \mathrm{Aa}$ & $43.78 \pm 0.74 \mathrm{Ab}$ & $41.59 \pm 2.28 \mathrm{Ab}$ & $40.31 \pm 0.68^{\mathrm{Ab}}$ \\
\hline & DS & $69.76 \pm 5.16 \mathrm{Aa}$ & $46.18 \pm 4.71 \mathrm{Ab}$ & $43.08 \pm 2.03 \mathrm{Ab}$ & $39.79 \pm 1.45^{\mathrm{Ab}}$ \\
\hline & DSC & $54.34 \pm 2.73 \mathrm{Ba}$ & $46.81 \pm 4.98 \mathrm{Ab}$ & $41.84 \pm 1.82 \mathrm{Abc}$ & $39.20 \pm 0.65^{\mathrm{Ac}}$ \\
\hline
\end{tabular}

For each cultivar, means $( \pm \mathrm{SD})$ within column with different uppercase letters were statistically different $(p<0.05)$ between treatments. For each treatment, means $( \pm \mathrm{SD})$ within a row with different lowercase letters were statistically different $(p<0.05)$ between cultivars.

\subsection{Weight Loss}

Generally, the weight loss of a tomato fruit increases progressively during the storage period and continues until the fruit attains full ripeness [31]. In this study, the percentage of weight loss increased over the storage period for all treated tomato cultivars stored in the three different treatments (Figure 2). 
Results showed that individual factors could influence variations in weight losses among groups exerted during different treatments (Table 3). The two- and three-way interactions between treatments, storage period, and cultivars also had a highly significant $(p<0.001)$ influence on the weight loss.

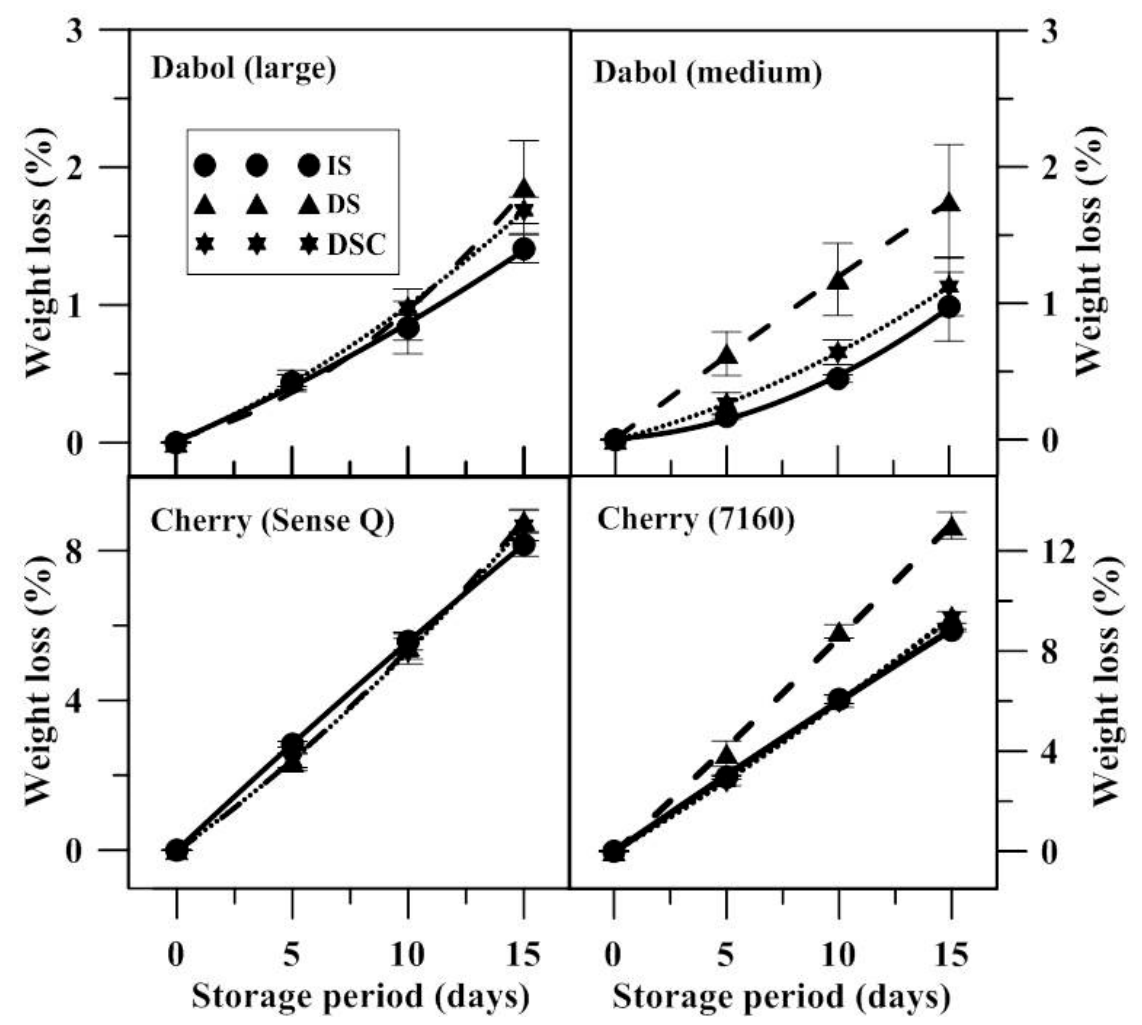

Figure 2. Changes in weight loss of four tomato cultivars over 15 days of storage under IS (immediate storage), DS (storage delayed $24 \mathrm{~h}$ ), and DSC (storage delayed $24 \mathrm{~h}$ under cover) postharvest treatments.

Table 3. Three-way ANOVA showing individual and interaction effect of the postharvest treatment (Tr), cultivar (C), and storage period (SP) on weight loss, firmness, total soluble solids (TSS), and hue angle of tomatoes.

\begin{tabular}{ccccccccccc}
\hline \multirow{2}{*}{ Item } & \multirow{2}{*}{ d.f. } & \multicolumn{2}{c}{ Weight Loss } & \multicolumn{2}{c}{ Firmness } & \multicolumn{2}{c}{ TSS } & \multicolumn{2}{c}{ Hue Angle } \\
\cline { 3 - 11 } & & $\boldsymbol{F}$ & $\boldsymbol{p}$ & $\boldsymbol{F}$ & $\boldsymbol{p}$ & $\boldsymbol{F}$ & $\boldsymbol{p}$ & $\boldsymbol{F}$ & $\boldsymbol{p}$ \\
\hline $\mathrm{Tr}$ & 2 & 136.93 & $<0.001$ & 5.90 & 0.004 & 0.11 & 0.892 & 17.01 & $<0.001$ \\
$\mathrm{SP}$ & 3 & 4522.07 & $<0.001$ & 85.07 & $<0.001$ & 11.91 & $<0.001$ & 88.12 & $<0.001$ \\
$\mathrm{C}$ & 3 & 4382.66 & $<0.001$ & 822.93 & $<0.001$ & 2225.21 & $<0.001$ & 279.39 & $<0.001$ \\
$\operatorname{Tr} \times \mathrm{C}$ & 6 & 71.93 & $<0.001$ & 3.77 & 0.002 & 4.11 & 0.001 & 16.51 & $<0.001$ \\
$\operatorname{Tr} \times \mathrm{SP}$ & 6 & 34.28 & $<0.001$ & 0.59 & 0.741 & 2.03 & 0.068 & 3.65 & 0.003 \\
$\mathrm{SP} \times \mathrm{C}$ & 9 & 840.09 & $<0.001$ & 8.26 & $<0.001$ & 10.28 & $<0.001$ & 11.94 & $<0.001$ \\
$\operatorname{Tr} \times \mathrm{SP} \times \mathrm{C}$ & 18 & 14.72 & $<0.001$ & 0.26 & 0.998 & 2.63 & 0.001 & 1.56 & 0.085 \\
\hline
\end{tabular}

A general increase in weight loss was observed in all the treatments, although the changes were slower in the IS treatment than in the delayed cooling treatments. After 15 days of storage, compared to other treatments, Dabol (large), Dabol (medium, Cherry (Sense Q), and Cherry (7160) tomato varieties treated with DS were found to have the highest weight loss values of $1.75 \%, 1.86 \%, 8.8 \%$, and $13.01 \%$, respectively. However, the IS-treated Dabol (large) variety showed the lowest weight loss of $0.98 \%$ after 15 days of storage.

The postharvest water loss of fruits and vegetables results from respiration and diffusion through the surface in horticultural products, leading to a deterioration in quality [34]. Even relatively small variations in relative humidity at a given temperature can cause a significantly higher vapor pressure 
deficit (VPD), leading to a significant difference in weight loss rates [35]. Delays in cooling could lead to longer exposure to higher VPD conditions, resulting in the weight loss of fruits and vegetables [36,37]. Crisosto et al. [38] found water loss to be a major negative impact of field delays before cooling for grapes. Pelletier et al. [39] reported a higher weight loss associated with a $4 \mathrm{~h}$ delay between the harvest and cooling of strawberries compared to fruits that were immediately cooled.

\subsection{Firmness}

The statistical analysis indicated that postharvest storage treatments had significant impact $(p<0.05)$ on the firmness of the tomato cultivars. The two-way interactions between treatments and storage period and the three-way interaction between treatment, storage period, and cultivars had no significant effect $(p>0.05)$ on the firmness of the tomatoes (Table 3). The main effects of storage period and cultivar had significant $(p<0.001)$ effects on the firmness of the stored tomatoes. However, the interaction between treatment and cultivars had a significant influence $(p<0.05)$ but the storage period and cultivar factors showed a highly significant influence $(p<0.001)$ on the firmness of the stored tomatoes.

As the storage period progressed, a loss in firmness was observed for IS-, DS-, and DSC-treated tomato varieties (Figure 3). Among the treatments, DS-treated Dabol (large), Dabol (medium), Cherry (Sense Q), and Cherry (7160) tomato varieties showed greater decreases in firmness from 15.79 to $10.19 \mathrm{~N}, 23.91$ to $14.54 \mathrm{~N}, 34.24$ to $20.14 \mathrm{~N}$, and 29.02 to $16.79 \mathrm{~N}$, respectively. IS-treated tomato varieties showed lower decreases in firmness, while among the cultivars, the Dabol (large) variety showed the lowest decrease in firmness, from 28.83 to $20.49 \mathrm{~N}$ after 15 days of storage.

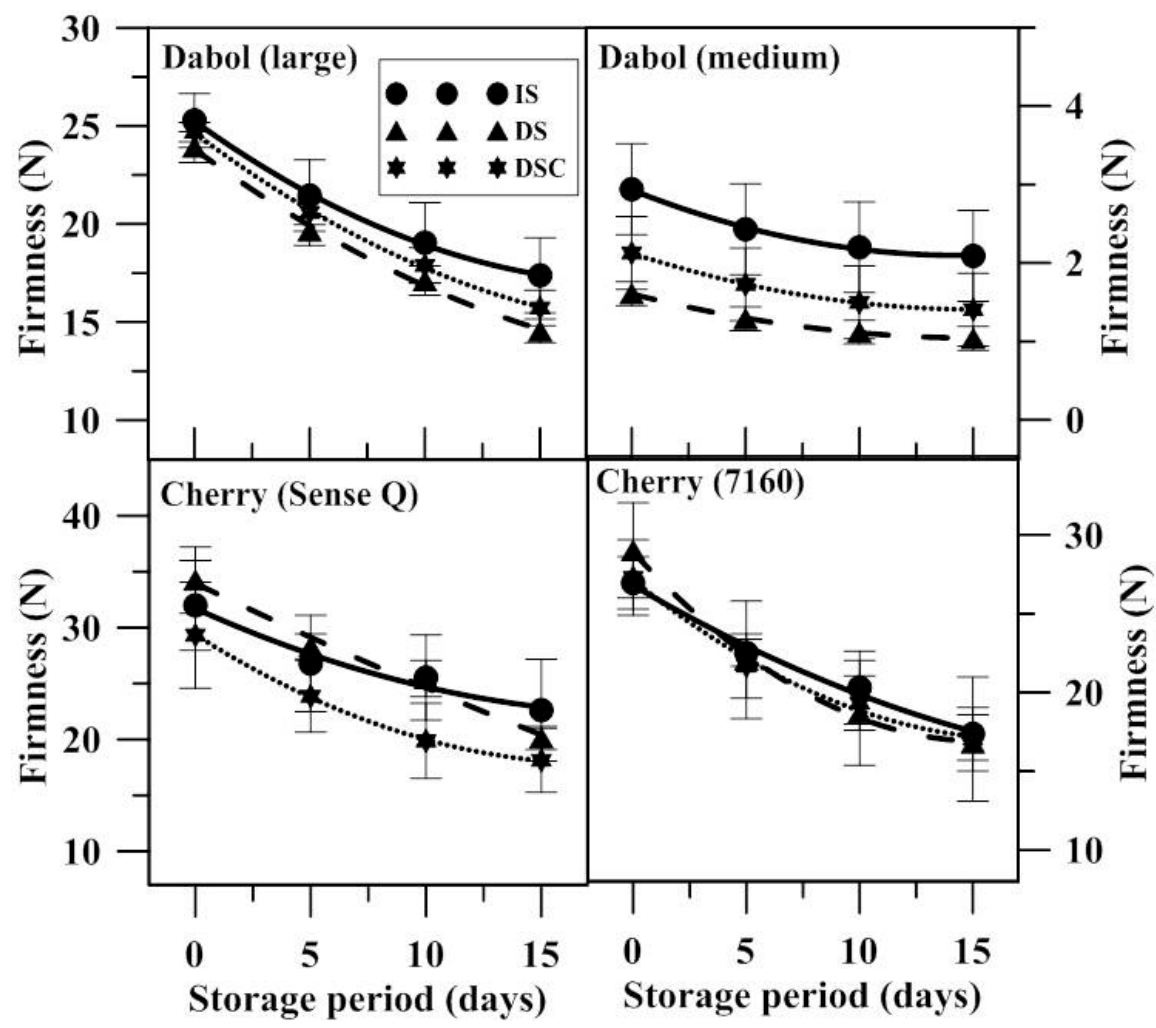

Figure 3. Changes in firmness of four tomato cultivars over 15 days of storage under IS (immediate storage), DS (storage delayed $24 \mathrm{~h}$ ), and DSC (storage delayed $24 \mathrm{~h}$ under cover) postharvest treatments.

Tolesa and Workneh [40] reported declines in the firmness of tomatoes harvested at the green, pink, and red maturity stages from 29 to $10 \mathrm{~N}, 25$ to $13 \mathrm{~N}$, and 20.5 to $10 \mathrm{~N}$, respectively, over a storage period of 21 days inside an evaporative cooler, which is in agreement with the present findings. Majidi et al. [41] reported that controlled atmosphere storage maintained tomato firmness better than 
cold storage during the first 10 days of storage, and that a steeper decline in firmness ( $65 \mathrm{~N}$ to $59 \mathrm{~N})$ was observed from 10 to 20 days of storage. The results of this study indicated that the immediate storage of tomatoes after harvesting could maintain tomato firmness better than the delayed cooling of tomatoes.

\subsection{Total Soluble Solids (TSS)}

The changes in TSS content of tomato varieties under the three treatments over the storage period, along with their fitted curves, are presented in Figure 4. Storage period and cultivar had a significant $(p<0.001)$ influence on the TSS content of the stored tomatoes (Table 3). However, postharvest storage treatment and interactions between treatment and storage period showed a non-significant effect on the TSS content. The two-way interaction between treatment and cultivar, storage period and cultivar had a significant $(p<0.05$ and $p<0.001)$ effect, while the three-way interaction between treatment, storage period, and cultivar had a significant $(p<0.05)$ effect on the TSS content.

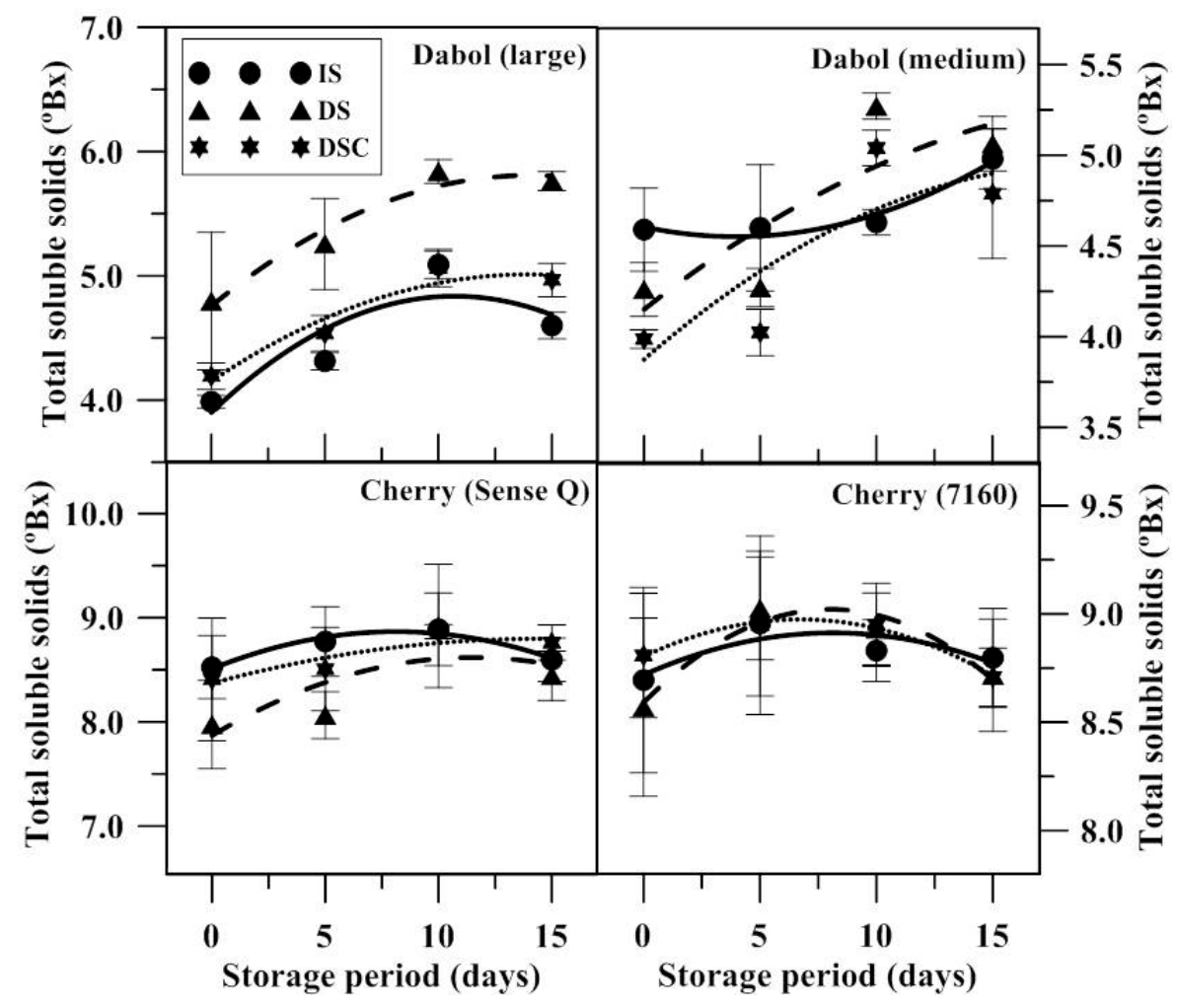

Figure 4. Changes in total soluble solid (TSS) content of four tomato cultivars over 15 days of storage under IS (immediate storage), DS (storage delayed $24 \mathrm{~h}$ ), and DSC (storage delayed $24 \mathrm{~h}$ under cover) postharvest treatments.

Throughout the storage period, IS-treated tomatoes showed minimum changes in the TSS content compared to the tomatoes treated with DS and DSC. The TSS changes of IS-treated tomatoes were found to be slower, which could be due to the slowing of metabolic activity and respiration rates, contributing to a slower change from carbohydrates to sugars [42]. The DSC-treated tomatoes showed lower changes than DS, which could be due to the effect of the cover reducing the temperature inside the tomato box [43]. Higher changes in the TSS content were observed for the Dabol (large) and Dabol (medium) varieties, which increased over 10 days of storage, followed by a decreasing trend thereafter. Cherry varieties showed lower changes in TSS content, and an increase was found after 10 and 5 days of storage for Cherry (Sense Q) and Cherry (7160) varieties, respectively, followed by a decrease.

Among the qualitative properties, soluble solid content has been associated with quality loss during tomato postharvest storage and can influence acceptance by consumers [44,45]. Majidi et al. [46] 
found that minimum changes in TSS values of tomatoes in controlled atmosphere storage increased from 5.2 to 5.59 over 40 days of storage, and then decreased to 5.18 after 90 days. Gharezi et al. [47] found a rapid initial increase in TSS content which then gradually decreased during the storage of cherry tomatoes at ambient and cold storage conditions, which is in agreement with the present findings.

\subsection{Hue Angle ( $\left.h^{\circ}\right)$}

Changes in the hue angle $\left(h^{\circ}\right)$ values of tomatoes during storage after the three different treatments are shown in Figure 5. The main factors (postharvest storage treatment, storage period, and cultivar) significantly $(p<0.001)$ influenced the hue angle values of the stored tomatoes (Table 3$)$. The two-way interactions between treatment and cultivar, treatment and storage period, and storage period and cultivar had a significant $(p<0.001, p<0.003$, and $p<0.001)$ influence on the hue angle values. The three-way interaction between treatments, storage period, and cultivars had no significant influence on the hue angle values of the tomato varieties.

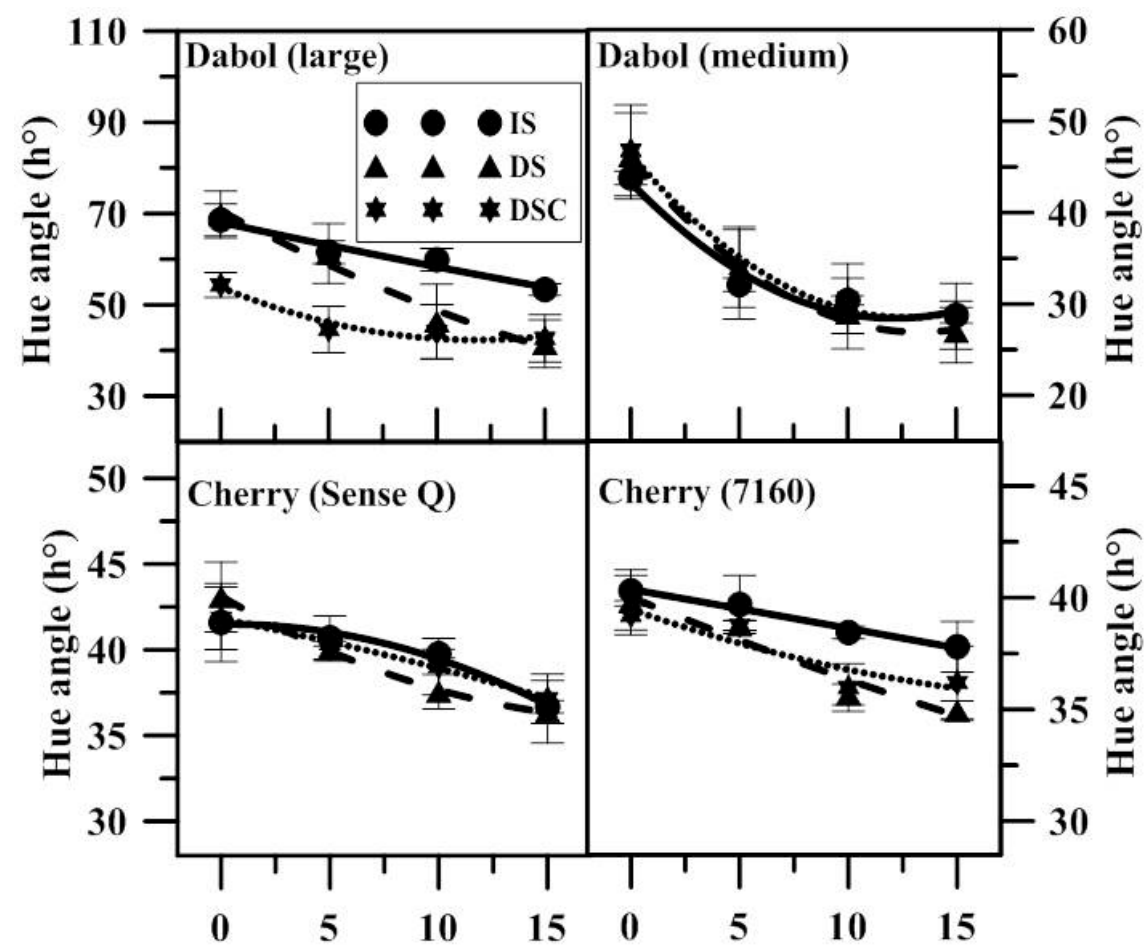

Storage period (days) Storage period (days)

Figure 5. Changes in hue angle $\left(h^{\circ}\right)$ of four tomato cultivars over 15 days of storage under IS (immediate storage), DS (storage delayed $24 \mathrm{~h}$ ), and DSC (storage delayed $24 \mathrm{~h}$ under cover) postharvest treatments.

The tomato samples of the Dabol (medium) variety stored under DS treatment experienced the highest decrease of hue angle values compared to the other tomato varieties. However, the hue angle values of the Cherry (7160) variety showed the least change. The hue angle values of the IS-treated tomato samples indicated slowed color development over 15 days of storage compared to the tomato samples treated under DS and DSC treatments.

Srinivasa et al. [48] observed a decrease of hue angle values during the storage of tomato fruits using eco-friendly films. Pinheiro et al. [49] also found a decrease in the hue angle values over a storage period of 30 days and recommended a storage temperature of $10^{\circ} \mathrm{C}$ to better preserve tomato quality, avoid chilling injuries, and extend shelf life, which is in agreement with our findings. The slowing down of color development could be due to physiological respiration, which could influence the quality of stored tomatoes throughout the storage period [40]. 


\section{Conclusions}

Harvested tomatoes require a sufficient shelf life to maintain acceptance from harvest to consumption. Conventionally, growers leave their tomatoes in the working space of the greenhouse for 1 to 2 days after harvest, with or without shade. Therefore, we examined the effect of such a cooling delay in the field on the quality of tomato fruits. DS and DSC treatments seemed to stimulate the deterioration of fruit quality, resulting in fast weight and firmness losses, higher changes in TSS content, and a fast decrease in hue angle values compared to IS-treated tomato samples. DSC-treated samples were better maintained than DS-treated samples due to the effects of the cover. The results of this study indicate the consequences of cooling delay for tomatoes stored in a controlled chamber, and highlight the importance of immediate cooling before transportation to processing and storage centers.

Author Contributions: Conceptualization, S.-O.C. and M.S.N.K.; methodology, S.-O.C.; software, M.S.N.K.; validation, M.S.N.K., S.-O.C. and W.-H.L.; formal analysis, M.S.N.K., M.A. and W.-H.L.; investigation, S.-O.C., W.-H.L. and S.-I.C.; resources, S.-O.C.; data curation, M.S.N.K. and M.A.; writing-original draft preparation, M.S.N.K.; writing-review and editing, S.-O.C., W.-H.L., and S.-I.C.; visualization, M.S.N.K. and M.A.; supervision, S.-O.C.; project administration, S.-O.C.; funding acquisition, S.-O.C. All authors have read and agreed to the published version of the manuscript.

Funding: This work was supported by the Korea Institute of Planning and Evaluation for Technology in Food, Agriculture and Forestry (IPET) through the Agriculture, Food and Rural Affairs Convergence Technologies Program for Educating Creative Global Leaders, funded by Ministry of Agriculture, Food and Rural Affairs (MAFRA) (Project No. 320001-4), Republic of Korea.

Conflicts of Interest: The authors declare that they have no conflict of interest.

\section{References}

1. Pék, Z.; Szuvandzsiev, P.; Nemenyi, A.; Helyes, L.; Lugasi, A. The effect of natural light on changes in antioxidant content and color parameters of vine-ripened tomato (Solanum lycopersicum L.) fruits. HortScience 2011, 46, 583-585. [CrossRef]

2. Dorais, M.; Ehret, D.L.; Papadopoulos, A.P. Tomato (Solanum lycopersicum) health components: From the seed to the consumer. Phytochem. Rev. 2008, 7, 231-250. [CrossRef]

3. Pék, Z.; Helyes, L.; Lugasi, A. Color changes and antioxidant content of vine and post-harvest ripened tomato fruits. HortScience 2010, 45, 466-468. [CrossRef]

4. Martí, R.; Roselló, S.; Cebolla-Cornejo, J. Tomato as a source of carotenoids and polyphenols targeted to cancer prevention. Cancers 2016, 8, 58. [CrossRef] [PubMed]

5. Perveen, R.; Suleria, H.A.R.; Anjum, F.M.; Butt, M.S.; Pasha, I.; Ahmad, S. Tomato (Solanum lycopersicum) carotenoids and lycopenes chemistry; metabolism, absorption, nutrition, and allied health claims-A comprehensive review. Crit. Rev. Food Sci. Nutr. 2015, 55, 919-929. [CrossRef]

6. Helyes, L.; Pék, Z.; Lugasi, A. Tomato fruit quality and content depend on stage of maturity. HortScience 2006, 41, 1400-1401. [CrossRef]

7. Anza, M.; Riga, P.; Garbisu, C. Effects of variety and growth season on the organoleptic and nutritional quality of hydroponically grown tomato. J. Food Qual. 2006, 29, 16-37. [CrossRef]

8. Tilahun, S.; Park, D.S.; Taye, A.M.; Jeong, C.S. Effect of ripening conditions on the physicochemical and antioxidant properties of tomato (Lycopersicon esculentum Mill.). Food Sci. Biotechnol. 2017, 26, 473-479. [CrossRef]

9. Raheem, D.; Shishaev, M.; Dikovitsky, V. Food system digitalization as a means to promote food and nutrition security in the Barents region. Agriculture 2019, 9, 168. [CrossRef]

10. Ben-Arie, R.; Lurie, S. Prolongation of fruit life after harvest. In Hand Book of Fruit Set and Development; Monselise, S.P., Ed.; CRC Press: Boca Raton, FL, USA, 1986; pp. 493-520.

11. Tolesa, G.N.; Workneh, T.S. Influence of storage environment, maturity stage and pre-storage disinfection treatments on tomato fruit quality during winter in KwaZulu-Natal, South Africa. J. Food Sci. Technol. 2017, 54, 3230-3242. [CrossRef]

12. Yahia, E.M. Postharvest physiology and biochemistry of fruits and vegetables. In Postharvest Physiology and Biochemistry of Fruits and Vegetables, 1st ed.; Yahia, E.M., Carrillo-López, A., Eds.; Woodhead Publishing: Duxford, UK, 2019; pp. 1-17. 
13. Raison, J.K.; Lyons, J.M. Chilling injury: A plea for uniform terminology. Plant. Cell Environ. 1986, 9, 685-686. [CrossRef]

14. Cantwell, M. Properties and Recommended Conditions for the Long-term Storage of Fresh Fruits and Vegetables. University of California: Davis, CA, USA, 2001.

15. Kitinoja, L.; Kader, A.A. Small-Scale Postharvest Handling Practices: A Manual for Horticultural Crops, 5th ed.; Postharvest Horticulture Series No. 8E; University of California, Postharvest Technology Research and Information Center: Davis, CA, USA, 2015.

16. Kabir, M.S.N.; Chowdhury, M.; Lee, W.H.; Hwang, Y.S.; Cho, S.I.; Chung, S.O. Influence of delayed cooling on quality of bell pepper (Capsicum annuum L.) stored in a controlled chamber. Emir. J. Food Agric. 2019, 31, 271-280.

17. Arah, I.K.; Amaglo, H.; Kumah, E.K.; Ofori, H. Preharvest and postharvest factors affecting the quality and shelf life of harvested tomatoes: A mini review. Int. J. Agron. 2015, 2015, 1-6. [CrossRef]

18. Qin, J.; Kim, M.S.; Chao, K.; Cho, B.K. Raman chemical imaging technology for food and agricultural applications. J. Biosyst. Eng. 2017, 42, 170-189.

19. Seo, Y.; Park, J.R.; Park, H.M. Evaluation of nonthermal plasma treatment by measurement of stored citrus properties. J. Biosyst. Eng. 2018, 43, 401-409.

20. El-Ramady, H.R.; Domokos-Szabolcsy, É.; Abdalla, N.A.; Taha, H.S.; Fári, M. Postharvest management of fruits and vegetables storage. In Sustainable Agriculture Reviews 15; Lichtfouse, E., Ed.; Springer: Cham, Switzerland, 2015; pp. 121-152.

21. Kader, A.A.; Barrett, D.M. Classification, composition of fruits, and postharvest maintenance of quality. In Processing Fruits, 2nd ed.; Barrett, D.M., Somogyi, L., Ramaswamy, H., Eds.; CRC Press: London, UK, 2005; pp. 3-22.

22. Nunes, M.C.N.; Nicometo, M.; Emond, J.P.; Melis, R.B.; Uysal, I. Improvement in fresh fruit and vegetable logistics quality: Berry logistics field studies. Phil. Trans. R. Soc. A. 2014, 372, 20130307. [CrossRef]

23. Thompson, J.; Cantwell, M.; Arpaia, M.L.; Kader, A.; Crisosto, C.; Smilanick, J. Effect of cooling delays on fruits and vegetable quality. Perish. Handl. Q. 2001, 105, 2-5.

24. Barrett, D.M.; Beaulieu, J.C.; Shewfelt, R. Color, flavor, texture, and nutritional quality of fresh-cut fruits and vegetables: Desirable levels, instrumental and sensory measurement, and the effects of processing. Crit. Rev. Food Sci. Nutr. 2010, 50, 369-389. [CrossRef]

25. Rahman, A.; Park, E.; Bae, H.; Cho, B.K. Hyperspectral imaging technique to evaluate the firmness and the sweetness index of tomatoes. Korean J. Agric. Sci. 2018, 45, 823-837.

26. Tomala, K.; Grzęda, M.; Guzek, D.; Głąbska, D.; Gutkowska, K. The effects of preharvest 1-Methylcyclopropene (1-MCP) treatment on the fruit quality parameters of cold-stored 'Szampion' cultivar apples. Agriculture 2020, 10, 80. [CrossRef]

27. Park, H.J. Development of advanced edible coatings for fruits. Trends Food Sci. Technol. 1999, 10, $254-260$. [CrossRef]

28. Kim, J.H.; Gu, J.R.; Kim, G.; Choi, S.; Yang, J.Y. Effect of storage temperature on the quality of tomato. Korean J. Food Nutr. 2010, 23, 428-433.

29. Tilahun, S.; Park, D.S.; Taye, A.M.; Jeong, C.S. Effects of storage duration on physicochemical and antioxidant properties of tomato (Lycopersicon esculentum Mill.). Hortic. Sci. Technol. 2017, 35, 88-97.

30. Taye, A.M.; Tilahun, S.; Park, D.S.; Seo, M.H.; Jeong, C.S. Effects of continuous application of $\mathrm{CO}_{2}$ on fruit quality attributes and shelf life during cold storage in cherry tomato. Hortic. Sci. Technol. 2017, 35, 300-313.

31. Pila, N.; Gol, N.B.; Rao, T.V.R. Effect of postharvest treatments on physicochemical characteristics and storage life of tomato (Lycopersicon esculentum Mill.) fruits during storage. Am. Eurasian J. Agric. Environ. Sci. 2010, 9 , 470-479.

32. Choi, G.W.; Kim, B.; Ju, H.; Cho, S.; Seo, E.; Kim, J.; Park, J.; Hammond, J.; Lim, H.S. Dual infections of Tomato mosaic virus (ToMV) and Tomato yellow leaf curl virus (TYLCV), or Tomato mosaic virus (ToMV) and Tomato chlorosis virus (ToCV), detected in tomato fields located in Chungcheongnam-do in 2017. Korean J. Agric. Sci. 2018, 45, 38-42.

33. Topuz, A.; Feng, H.; Kushad, M. The effect of drying method and storage on color characteristics of paprika. LWT-Food Sci Technol. 2009, 42, 1667-1673. [CrossRef] 
34. Madani, B.; Mirshekari, A.; Imahori, Y. Physiological responses to stress. In Postharvest Physiology and Biochemistry of Fruits and Vegetables; Yahia, E.M., Carrillo-López, A., Eds.; Woodhead Publishing: Cambridge, MA, USA, 2019; pp. 405-423.

35. Rodov, V.; Ben-Yehoshua, S.; Fierman, T.; Fang, D. Modified-humidity packaging reduces decay of harvested red bell pepper fruit. HortScience 1995, 30, 299-302. [CrossRef]

36. Toivonen, P.M.A. Postharvest physiology of vegetables. In Handbook of Vegetables and Vegetable Processing; Sinha, N., Hui, Y.H., Evranuz, E.Ö., Siddiq, M., Ahmed, J., Eds.; Wiley-Blackwell Publishing: Ames, IA, USA, 2010; pp. 199-220.

37. Toivonen, P.M.A.; Hodges, D.M. Abiotic stress in harvested fruits and vegetables. In Abiotic Stress in Plants-Mechanisms and Adaptations; Shanker, A.K., Venkateswarlu, B., Eds.; InTech: Rijeka, Croatia, 2011; pp. 39-58.

38. Crisosto, C.H.; Smilanick, J.L.; Dokoozlian, N.K. Table grapes suffer water loss, stem browning during cooling delays. Calif. Agric. 2001, 55, 39-42. [CrossRef]

39. Pelletier, W.; Brecht, J.K.; Nunes, M.C.N.; Emond, J.P. Quality of strawberries shipped by truck from California to Florida as influenced by postharvest temperature management practices. HortTechnology 2011, 21, 482-493. [CrossRef]

40. Tolesa, G.N.; Workneh, T.S.; Melesse, S.F. Modelling effects of pre-storage treatments, maturity stage, low-cost storage technology environment and storage period on the quality of tomato fruit. CyTA-J. Food 2018, 16, 271-280. [CrossRef]

41. Majidi, H.; Minaei, S.; Almassi, M.; Mostofi, Y. Tomato quality in controlled atmosphere storage, modified atmosphere packaging and cold storage. J. Food Sci. Technol. 2014, 51, 2155-2161. [CrossRef] [PubMed]

42. Ali, A.; Muhammad, M.T.M.; Sijam, K.; Siddiqui, Y. Effect of chitosan coating on the physicochemical characteristics of Eksotika II papaya (Carica papaya L.) fruit during cold storage. Food Chem. 2011, 124, 620-625. [CrossRef]

43. Mahmood, A.; Hu, Y.; Tanny, J.; Asante, E.A. Effects of shading and insect-proof screens on crop microclimate and production: A review of recent advances. Sci. Hortic. 2018, 241, 241-251. [CrossRef]

44. Guillén, F.; Castillo, S.; Zapata, P.J.; Martínez-Romero, D.; Valero, D.; Serrano, M. Efficacy of 1-MCP treatment in tomato fruit: 2-Effect of cultivar and ripening stage at harvest. Postharvest Biol. Technol. 2006, 42, $235-242$. [CrossRef]

45. Zapata, P.J.; Guillén, F.; Martínez-Romero, D.; Castillo, S.; Valero, D.; Serrano, M. Use of alginate or zein as edible coatings to delay postharvest ripening process and to maintain tomato (Solanum lycopersicon Mill.) quality. J. Sci. Food Agric. 2008, 88, 1287-1293. [CrossRef]

46. Majidi, H.; Minaei, S.; Almasi, M.; Mostofi, Y. Total soluble solids, titratable acidity and repining index of tomato in various storage conditions. Aust. J. Basic Appl. Sci. 2011, 5, 1723-1726.

47. Gharezi, M.; Joshi, N.; Sadeghian, E. Effect of post harvest treatment on stored cherry tomatoes. J. Nutr. Food Sci. 2012, 2, 157. [CrossRef]

48. Srinivasa, P.C.; Prashanth, K.V.H.; Susheelamma, N.S.; Ravi, R.; Tharanathan, R.N. Storage studies of tomato and bell pepper using eco-friendly films. J. Sci. Food Agric. 2006, 86, 1216-1224. [CrossRef]

49. Pinheiro, J.; Alegria, C.; Abreu, M.; Gonçalves, E.M.; Silva, C.L.M. Kinetics of changes in the physical quality parameters of fresh tomato fruits (Solanum lycopersicum, cv. 'Zinac') during storage. J. Food Eng. 2013, 114, 338-345. [CrossRef]

(C) 2020 by the authors. Licensee MDPI, Basel, Switzerland. This article is an open access article distributed under the terms and conditions of the Creative Commons Attribution (CC BY) license (http://creativecommons.org/licenses/by/4.0/). 